\title{
The Legacy of Margaret Thatcher-A Critical Assessment
}

\author{
Paul Stepney \\ University of Tampere, Tampere, Finland \\ Email: paul.stepney@uta.fi
}

Received 16 September 2013; revised 18 October 2013; accepted 26 October 2013

Copyright (C) 2014 Paul Stepney. This is an open access article distributed under the Creative Commons Attribution License, which permits unrestricted use, distribution, and reproduction in any medium, provided the original work is properly cited. In accordance of the Creative Commons Attribution License all Copyrights (C) 2014 are reserved for SCIRP and the owner of the intellectual property Paul Stepney. All Copyright (C) 2014 are guarded by law and by SCIRP as a guardian.

\section{Abstract}

The recent death of Margaret Thatcher sparked some very strong and divided opinions throughout Europe, United States and across the globe. Her death made headline news, such was her notoriety as a person who not only sought to change history but was instrumental in reshaping it especially during the 1980s and 1990s. Although Thatcher may have passed away, the ideas underpinning Thatcherism are alive and well, and importantly, continue to exert a decisive influence on the wider political and economic landscape. The heart of Thatcher legacy is a fundamental contradiction neatly exposed by the current global economic crisis. Thatcherism, with its belief in the efficacy of the market and determination to roll back the frontiers of the state, ought to have been thoroughly discredited given that deregulation of the financial markets has led to many of today's problems. However, despite the financial crisis requiring massive government bailouts on an unprecedented scale, neoliberal thinking in the best Thatcherite traditions continues unabated. This is the paradox of Thatcherism. Now several months after her funeral is an appropriate time to make a rational assessment of her legacy, noting her achievements alongside the bitter controversy about the highly individualistic and divided society she helped to create.

\section{Keywords}

Thatcherism; Individualism; Neoliberalism; Privatization; Nationalism

\section{Introduction}

The recent death of Margaret Thatcher has sparked some very strong and divided opinions not just in Britain but throughout Europe, United States and across the globe. Her death on 8th April 2013 certainly made headline 
news across the globe, such was her notoriety and significance as a person who not only sought to change history but was instrumental in reshaping it especially during the 1980s and 1990s.
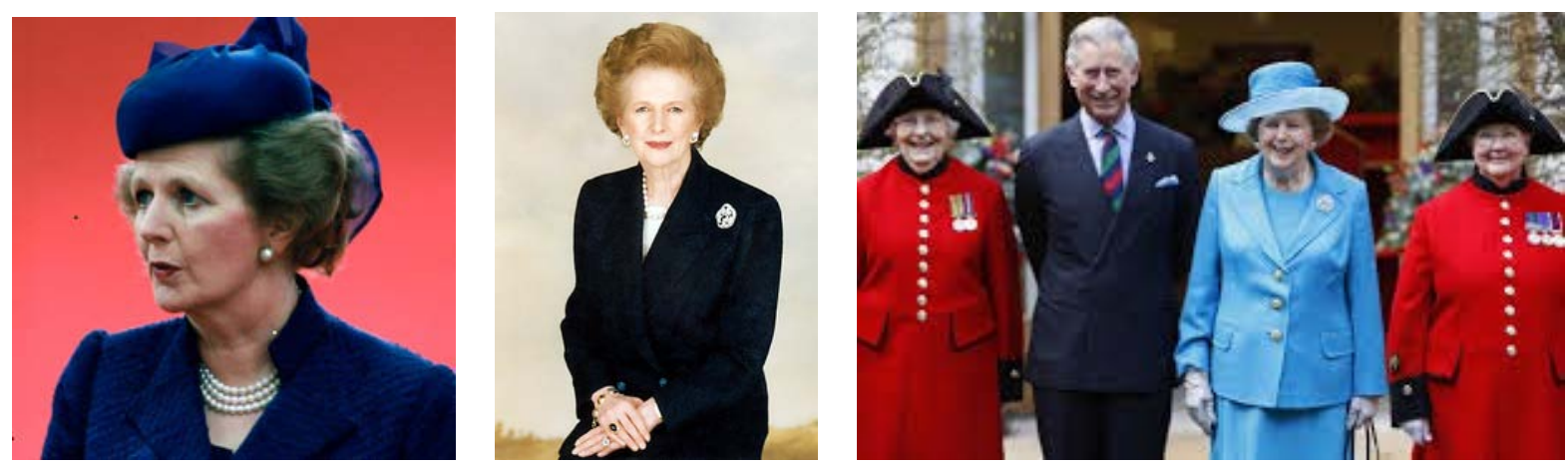

Her funeral understandably generated strong emotional reactions in a highly charged atmosphere, but now several months later it is an appropriate time to try and make a cool and rational assessment of her legacy. The reasons for this are quite clear. Though Thatcher may have passed away, the ideas underpinning Thatcherism are still alive, and more importantly, continue to exert a decisive influence on the wider political and economic landscape. In UK, David Cameron's leadership of the Conservative party is increasingly being questioned by Thatcherite Euro-sceptic backbenchers. The United Kingdom Independence Party (UKIP) has enthusiastically taken on the Thatcher legacy abandoned by Cameron and significantly is having considerable electoral success with its anti EU stance. Criticizing Brussels has become increasingly popular with the British public. The problem of EU membership which Thatcher successfully renegotiated has assumed increasing importance as the crisis in the Eurozone states rumbles on with no solution in sight. In fact, no matter whether it is the problem of Britain's relationship with Europe or domestic policy, it is difficult to find a contemporary political issue where the shadow of Lady Thatcher does not fall on.

The heart of Thatcher legacy is a fundamental contradiction neatly exposed by the current global economic crisis. Many political commentators (not just those on the Left) are saying that Thatcherism, with its belief in the efficacy of the market and determination to roll back the frontiers of the state, ought to have been thoroughly discredited. However, not only has this not happened, but also it would see that contemporary solutions appear to be ineffective and indecisive because quite simply they lack the Maggie Thatcher touch. This is somewhat bizarre, given that Thatcher style deregulation of the financial markets has contributed, if not causing many of today's problems:

- the irresponsible risk taking behavior of many leading banks in the US and Europe who traded debt on a massive scale, with a bonus culture that encouraged their traders to make reckless investments in property and the high risk Derivatives or Hedge Fund market leading to finance capitals darkest hour... see [1] and [2] on the folly and alchemy of austerity.

- the inadequate and inept governmental regulation of Wall Street, the City of London and other stock markets around the world.

However, despite these problems requiring massive government bailouts on an unprecedented scale, neoliberal thinking in the best Thatcherite traditions continues unabated. Furthermore, our political leaders appear at best apologetic and at worst unashamed of the problems the crisis has caused... the current crisis in the Eurozone links clearly to the problems of debt, uneven development and growth, regional inequalities throughout Europe, alternative forms of government regulation in different EU member states and the role of quasi-independent institutions including the European Central Bank. According to Simon Jenkins [3, p. 30] "the Banks persuaded the world that they were too big to fail and their leaders too saintly to atone for it and... showered with public money, they duly recovered while everyone else went poor". This is the paradox of Thatcherism, particularly in the context of the current global economic crisis. So where did it all begin?

\section{Margaret Thatcher-The Early Years and Significant Influences}

Margaret Thatcher was born Margaret Roberts, a grocers daughter from the market town of Grantham in Lin- 
colnshire in 1925 (not a millionaire from a posh and privileged background like David Cameron and other members of the present rather elitist British cabinet). Her father was a Methodist lay preacher who owned 2 grocers shops and the family lived above one of them. Margaret was brought up as a strict Wesleyan Methodist with emphasis on personal faith, holiness and moral responsibility. Methodists were not as strict as other Christian sects, such as the Calvinists, until it came to the matter of alcohol. Here the "evils of drink" were preached in Methodist chapels throughout Britain and on this John Wesley (the founding father of Methodism) was probably a prophet ahead of his time given the level of alcohol abuse prevalent throughout the developed world. After studying chemistry at Somerville College Oxford, Margaret Roberts entered politics and joined the Conservative party fighting a number of unsuccessful elections. She married Denis Thatcher in 1951 and as is customary in Britain took his surname, had two children Carol and Mark who were twins. She was eventually elected as the MP for the safe conservative seat of Finchley in North London.

Margaret Thatcher began to attend lunches at the Institute for Economic Affairs in London, a right wing think tank whose members were disciples of the philosopher and economist Friedrich von Hayek. She read von Hayek's political texts including The Road to Serfdom (1944) and was in particular influenced by his classical liberal analysis, commitment to individualism and the free market, opposition to Keynesian economics and state planning, and quickly came to the view that the welfare state encouraged dependency and was a drain on Britain's prosperity. She took these classical liberal ideas, Methodist values and worship for the free market with her as she rose up the political ladder.

\section{Margaret Thatcher-Britain's Prime Minister 1979-1990}

Margaret Thatcher's political career and rise to high office culminating in becoming prime minister can only be described as meteoric. She quickly rose up through the Conservative party to become Education minister in Edward Heath's Conservative government of the early 1970s. In this role she will be remembered, amongst other things, for withdrawing free milk for children aged 7 - 11 in Britain's primary schools. This decision, as we now know was forced upon her by the treasury, made her deeply unpopular with the public. Further, it gave her a foretaste of what was to become one of the unfortunate hallmarks of her political career. Thatcher later claimed that she had learned an important lesson concerning the folly of taking a large calculated political risk for modest financial gain. However, she was to make a similar mistake over the "poll tax" near the end of her premiership in 1988 which made her even more unpopular and ultimately contributed to her downfall in 1990.

After the free school milk fiasco the Conservatives duly lost the 1974 general election to Labour. Later in 1975 Margaret Thatcher became leader of the Conservative party, now in opposition. She then won the 1979 general election and became Britain's first and only female Prime Minister. However, it was not very long before she began to make her mark domestically with a strong monetarist policy to manage the economy (control of inflation through control of the money supply using interest rates... von Hayek's influence again along with the American economist Milton Friedman). She introduced stricter immigration controls and tough policing in the aftermath of 1981 summer riots in many UK cities. Another set of policies involved the privatization of public utilities (gas, water, telecommunications and more controversially railways) along with welfare reform complemented by a tough labour market activation policy. Thatcher was also active on the world stage and people outside of the UK will probably remember seeing her on TV news programs engaging in debate with leaders in United States, the Soviet Union, China and across Europe.

She spoke out about the threat of Russian world domination and quickly became known as the "Iron lady" after the Soviet Defence ministry newspaper krasnaya Zvezda branded her a "strong willed woman and tough uncompromising leader" who seemed locked into the language of the cold war. Apparently Margaret Thatcher was very comfortable with this "Iron Lady" image and swiftly put it to her political advantage. Thus, the Iron lady began to influence East West relations, made overtures to the White House and US politicians, and looked for an opportunity to "do business" with the Russian leadership.

Margaret Thatcher's attempts to replace the cold war with détente gathered pace once Mikhail Gorbachev entered the Kremlin and set the Soviet Union on a road of irreversible reform. Gorbachev later said of Thatcher in his blog that "Our first meeting in 1984 marked the beginning of a relationship that was at times difficult, not always smooth, but was treated seriously and responsibly by both sides". After that meeting, months before Gorbachev succeeded Chernenko as Soviet leader, Thatcher returned the compliment and famously said of Gorbachev: "We can do business together". Margaret Thatcher, an enemy of communism, has said many times 

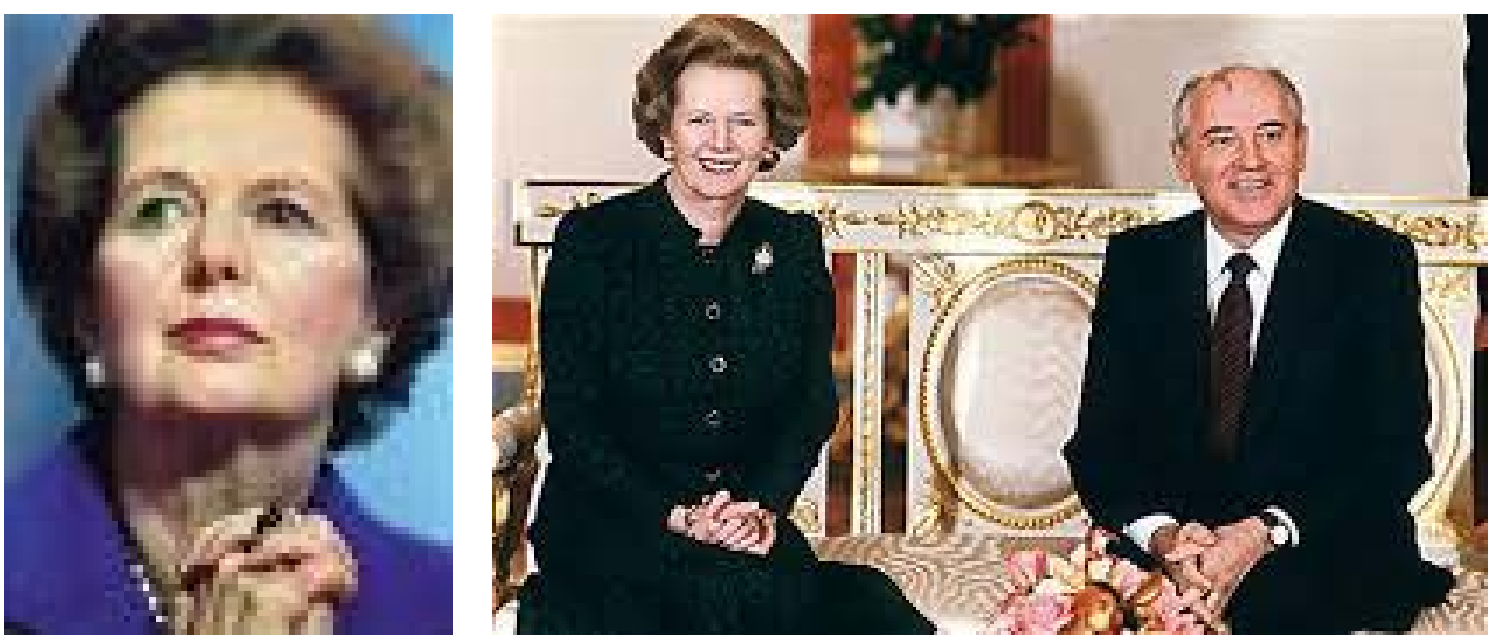

that she and Gorbachev firmly believed in their respective nation's political system and were never going to change one another, but their relationship helped bring about significant change. In particular the dialogue between Thatcher and Gorbachev created a degree of mutual trust between Britain, Russia and the United States (more about Ronald Reagan later) and this created conditions that helped to tear down the Iron Curtain and eventually led to the fall of the Berlin Wall.

\section{Achievements and Problems-Changing the Face of British Politics}

At the time when she became prime minister in May 1979 Britain had entered a period of sustained economic stagnation and industrial decline. Its traditional industries of coal, iron and steel, railways and shipbuilding had become increasingly uncompetitive in global markets. Further, its public welfare services built upon the twin legacy of Keynesian economics and Beveridge social insurance, with commitments to universalism, fairness and "free" access at the point of use, were judged by the 1960s to have become highly inefficient and in need of urgent reform. Britain endured a recession in the 1970s that had seen Dennis Healey, the Labour government's Chancellor of the exchequer (Finance minister), dragged off a plane at London Heathrow airport to attend a meeting of the IMF where the UK's request for financial assistance was being discussed. In all these areas reform was inevitable. However, what still had to be decided was how to go about the process of reform and whether the social casualties of industrial change would be protected. In both these areas Margaret Thatcher's market led approach resulting in widespread privatization, tough US style policing and welfare reform were all policies that divided the nation and increased the gap between rich and poor. In addition her uncompromising "school mistress" style, where she showed little understanding about the lives of ordinary working people and even less empathy for the problems of the poor, created much bitterness and social division.

\section{Special Relationship between Britain and United States}

The special relationship that Margaret Thatcher developed with Ronald Reagan quickly became a media journalists dream: Cowboy movie actor fresh from acting with John Wayne rides shotgun with Iron lady and they both end up doing business with Mikhail Gorbachev... Wow for journalists and TV news correspondents throughout the Western World it doesn't get much better than this! Significantly Margaret Thatcher helped to cement and re-establish UK/US economic and foreign policy after a period when relations post-the Vietnam war, Richard Nixon and Watergate had seen them cool considerably. But this didn't deter Thatcher who set about her political love affair with Ronald Reagan in some style and became a frequent visitor to the White House. Thatcher was so popular in the US that George Bush who followed on from Reagan and even President Obama today appear to be saddled with the legacy of that special relationship built upon neoliberal orthodoxy, a Republican majority in Congress and sharing of economic and military intelligence. Critical commentators in the United States, such as economics Professor Paul Krugman, suggest that the legacy continues to hamper US welfare reform and attempts by a Democrat president to stimulate growth by state investment [1]. 

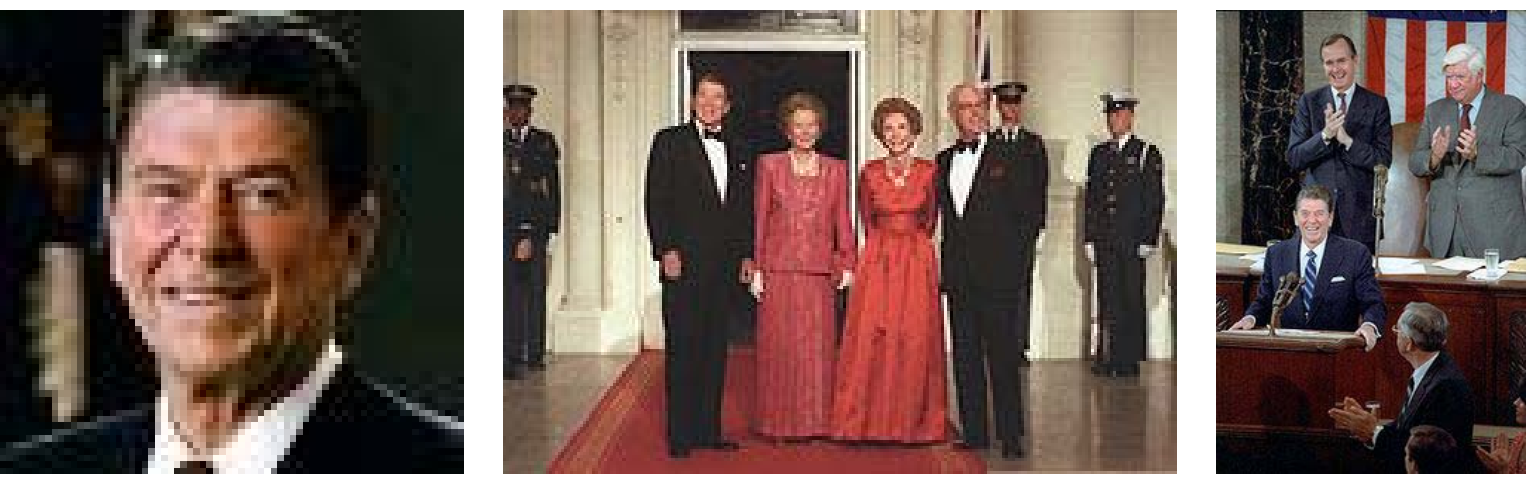

Perhaps most of all Thatcher was seen in the United States as a Churchillian figure that stood alongside America in times of conflict and largely supported NATO and US foreign policy. Reagan supported Thatcher morally and from a distance during the Falklands war not wishing to disturb US relations with South America. Whereas later Tony Blair didn’t use similar smart judgment over Iraq but felt compelled to send troops to back George Bush—as it turned out a very questionable political decision, if not mistake.

\section{The View from Europe: "Maggie Thatcher Can You Hear Me... Your Boys Took a Hell of a Beating" (Bjørge Lillelien, 1981)}

Reactions to Margaret Thatcher in Europe were often negative if not hostile. The main reasons for this were her anti-federalist criticism of European institutions, opposition to European integration and the more individualistic society she helped to create. The amusing quote of the Norwegian football journalist Bjørge Lillelien in the aftermath of Norway's famous victory over England in 1981 rather sums up a view that could be found at the time in many European counties [4].

Britain's relationship with the EU under Thatcher had become strained especially when she went to Brussels in 1984 to renegotiate a rebate of Britain's contribution to the then European Community. Her argument was that Britain was one of the largest contributors but received the second lowest benefit from the common agricultural policy. She was successful which meant the other member states, particularly France, effectively paying more to offset Britain's rebate-an outcome that increased her popularity at home but made her even more unpopular in Europe.

Thatcher's hostility towards European_integration increased during her premiership, particularly after her third election victory in 1987. During a speech in Bruges in 1988 she outlined her opposition to proposals from the European Community (EC), forerunner of the EU for a federal structure and increased centralisation of decision making. Thatcher and the Conservative party had supported British membership of the EC back in 1975 but she believed that the role of the institution should be limited to ensuring free trade and effective competition. Further, she feared that the approach in Brussels was at odds with her views on smaller government and deregulation. In her Bruges speech she remarked "We have not successfully rolled back the frontiers of the state in Britain, only to see them re-imposed at a European level, with a European super-state exercising a new dominance from Brussels”. Thatcher was firmly opposed to the UK's membership of the Exchange Rate Mechanism, a forerunner to European monetary union and the creation of the Euro currency and Eurozone, believing that it would constrain the British economy. So when the Euro was created Britain predictably opted out and kept its own currency (GBP).

Margaret Thatcher's influence was not just that she changed the nature and direction of the Conservative party making it pro-US, more Euro-sceptical and anti EU, but exerted a decisive influence on opposition politicians as well. She certainly influenced politicians who followed her, in particular Tony Blair, and set the parameters for the rise of New Labour in the UK. Her influence on the British Labour party is perhaps one of her most notable achievements. Tony Blair adopted many of Thatcher's policies and in creating New Labour abandoned its socialist principles and created a party of the centre (some would argue centre right) believing that this was necessary for electoral success.

The trade unions had been attacked by Thatcher at the time of the miners' strike in 1984 and they never really 


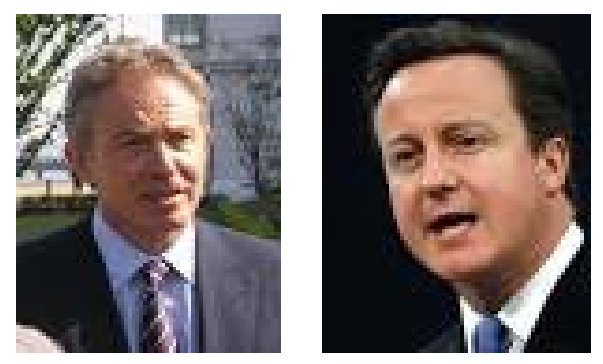

recovered. When Blair became prime minister in 1997 many wondered whether the unions would regain the influence they had exerted on the old Labour government back in the 1970s. However, this was not to be and their relationship with New Labour became more distant and unpredictable. The consequences of New Labour's move to the Right, the demise of trade unions, continuation of Thatcherite market led reform of public services and further privatization has been significant. The British Left has been in retreat ever since Thatcher's time in office which undermines democracy as we now have 3 main political parties in the UK all propagating centre-right policies. Opposition and resistance where it exists at grassroots level has little connection with the established political system and in welfare services, professionals such as social workers have become... "the dog that didn't bark" in the face of Thatcherite style reform and the long march of managerialism-see the authors contribution to an article written before her death, on whether a Tory can be a social worker [5].

\section{The Rise of Nationalism in Europe-" "Patriotism: The Last Refuge of the Scoundrel" (Samuel Johnson, 1775)}

The death of Margaret Thatcher could paradoxically create a climate conducive to the return of a more extreme far Right form of Thatcherism rather than the Thatcherism of the 1980s or indeed David Cameron's compassionate Conservatism. The latter is now openly derided as a weak side show by those on the far right [6] or interpreted by those on the Left as an apologist for the excesses of corporate Britain [7]. The political far Right are getting stronger and making gains all over Europe as people become increasingly cynical and disillusioned with mainstream politicians and the established political parties. Many people no longer bother to vote in the UK and the "turn out" for local council elections is often as low as $20 \%$. The young are not interested and say that they find politicians boring, while older people are apathetic or cynical as they have heard it all before. This has created a political void or hollow at the centre of British politics, which the far right have been quick to exploit.

In Britain the UK Independence Party (UKIP) which is anti EU and calls for strict control of immigration has become increasingly influential. Its leader Nigel Farage a proclaimed admirer of Margaret Thatcher is frequently on TV and is perceived as a solid reliable trustworthy patriotic politician who has inherited the Thatcher legacy at a time when David Cameron and other mainstream politicians appear to have abandoned it. UKIP are now making significant gains in local elections and has become a viable alternative to the 3 main established political parties for many "free born Englishmen" (a term that originated from the ideas of Thomas Paine [8]). Paine argued that popular political revolution is permissible when a government does not safeguard its people and uphold their natural rights.
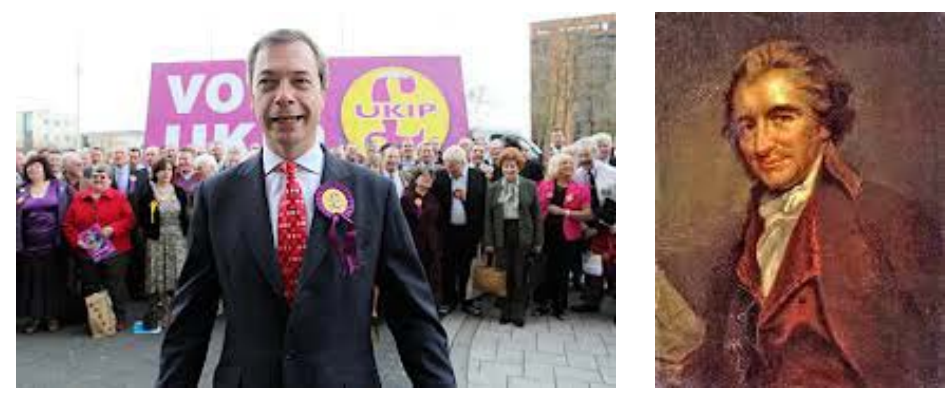

In France it is the deeply patriotic Jean Marie Le Pen and his determined daughter Marine Le Pen who hold political rallies waving the French flag and march to the tune of La Marseillaise. In Holland the patriotic anti- 
islamist Geert Wilders, although no longer part of the Dutch coalition government, remains highly influential. In Finland the True Finn party of Timo Soini (although not a far Right party in the traditional sense, but nonetheless nationalistic and anti EU) now command something like $20 \%$ of the popular vote... and so one could go on and on right across Europe where far Right, anti EU/Euro-sceptic politicians wave patriotic flags of Nationalism, call for an end to immigration and salute the abiding memory of leaders such as Margaret Thatcher.
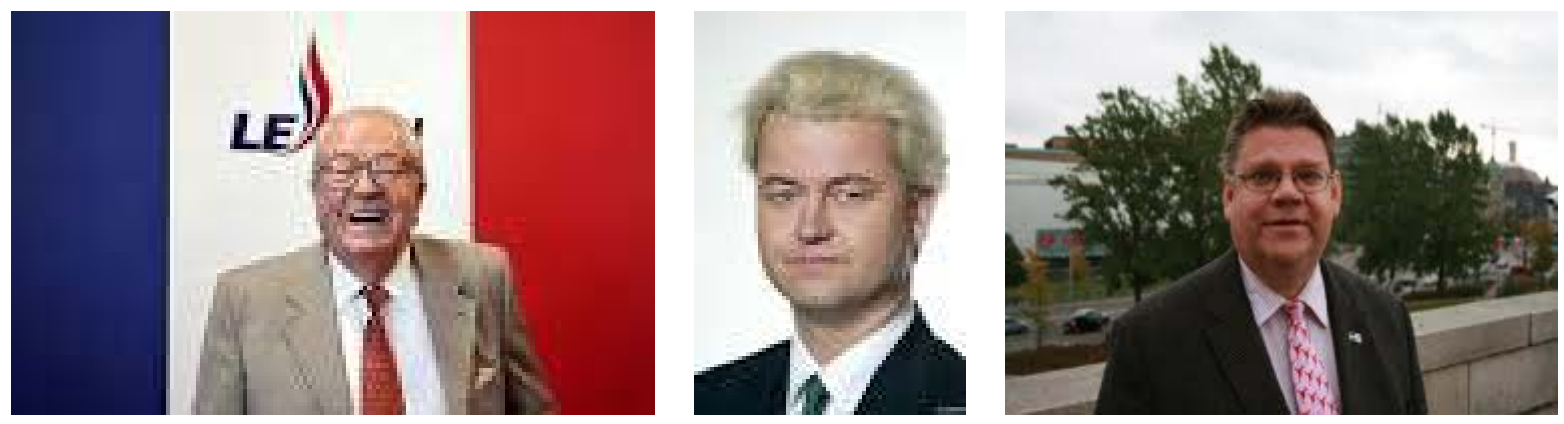

It is easy to get carried away of course when singing La Marseillaise and exaggerate the influence of the far Right but... they are certainly making gains everywhere and we live in similar economic, political and social conditions that led to the rise of Adolf Hitler in Germany in the 1930s. The death of Thatcher may well encourage those on the far Right that the time has come to push forward their ideas. For an example of how far right thinking enters the mainstream of middle England see Peter Hitchens [6] where he says Maggie Thatcher was actually “a tragic failure” as she didn't go far enough and politicians since have watered down many of her fundamental ideas. He argues that the new private companies like British Telecom, private Water companies etc. that have taken over running public utilities in the UK are just as bad if not worse than the old state monopolies. This is a view that many citizens will doubtless share. In general the new private companies running public utilities in the UK have been heavily subsidized by the state, but quickly introduced higher charges for providing an inferior service. The regulation of such companies has been light touch and largely ineffective.

\section{Reactions to Her Death}

The day after Margaret Thatcher died Britain's current Prime Minister, David Cameron, went out in Downing Street to hold a press conference and paid tribute to her as a great leader. However, at the same time he has sought to distance himself from the Thatcher legacy particularly in relation to rampant individualism. Margaret Thatcher had once said that there was no such thing as society. Cameron's alternative to Thatcherism is to promote "compassionate conservatism" and the notion of the "Big Society" even though many are doubtful whether this will make any difference. Relying on Big society volunteers and mutual self-help is of course extremely convenient at a time of budget constraint and cuts to public services [7]. It may help in pleasant and relatively wealthy Oxfordshire villages where Cameron is an MP, but is likely to do little to tackle the problems of poverty and unemployment in disadvantaged areas and the run down inner cities.

There have been mixed reactions across Europe to her death at a time of recession and crisis in a global market that Margaret Thatcher helped to deregulate, enhance and warmly celebrate. Judgment of her legacy will thus be strongly contested. People tend to either love her or loathe her and whilst I personally and professionally fought against many of her policies on welfare reform during the 1980s and 1990s, and strongly disagreed with most of what she said and stood for... I would not go so far as to go out and actively celebrate her death. This in my view is distasteful and disrespectful and undermines rational assessment of her legacy. It also allows those on the far Right to label such opposition when taken out on to the streets as mindless acts indicative of "spiteful, immature loathing unleashed among foolish ill-mannered people by her death” [6, p. 35].

\section{Conclusions-Margaret Thatcher's Legacy}

The death of Margaret Thatcher will be lamented by big business, the City of London, Wall Street, Bankers everywhere, industrialists and Rupublican politicians in the United States, far Right politicians in Europe as well as 
many backbench Tory MPs. The millionaires in the cabinet around David Cameron though outwardly and superficially supportive of Thatcherism, are actually quite ambivalent if not worried by her legacy. The reason for this is captured beautifully by Andrew O'Hagan [9, p. 18] writing in the New York Review:

Margaret Thatcher's main achievement... was to move the spiritual headquarters of the Conservative party from the elitist Carlton Club to the working-class housing estates of Britain. She always slightly hated England's elite... but by the end she left Britain a greedier and seedier place.

So for all her efforts to reshape Britain she never quite forgot that she was a grocer's daughter from the small market town of Grantham in Lincolnshire who rose to high office, not a member of the British upper class. Maggie quickly realized that to achieve electoral success in Britain she had to win over the hearts and minds of the respectable white working class of middle England... epitomised by people in places like Basildon in Essex. Many people in Basildon had previously been supporters of the Labour party, so she set about wooing them by giving council tenants the right to buy their council house at a subsidised price. Further she told them that their hard earned taxes would be put to good use in reformed (slimmed down) public services, whilst appeasing their fears about immigration and mistrust of everything in Europe by negotiating a rebate from the EU and imposing stronger border controls. She also received significant backing from Rupert Murdoch's newspaper empire in this quest.

Margaret Thatcher's most obvious achievements were on the world stage where, as we have noted, she sought to change East/West relations and helped to bring about the end of the cold war by supporting Gorbachev in his twin policies of perestroika and glasnost (restructuring and greater openness). However, there were also clear economic as well as ideological reasons for "doing business" with the Russian leadership and opening up new markets for trade among Britain, United States, Europe and Russia. So Thatcher will be remembered for her contribution to world peace and stability, but at the same time economic growth and capital penetration were high on her political and economic agenda.

Britain's extensive public services were reformed by introducing the mechanisms of the market, splitting the purchase of services from those who provided them, to try and reduce costs, alongside the introduction of new public management to oversee the process. The National Health Service (NHS) often seen as the jewel in the crown of the Welfare State was subject to market based reform whilst Mrs Thatcher claimed that the NHS was "safe in my hands". In fact she introduced privatization by stealth through the back door by creating a number of quasi markets [10]. By the end of Thatchers premiership, the introduction of CCTV cameras in British cities was heralded as a major crime prevention strategy and part of her "get tough on crime" policy—something Tony Blair enthusiastically reinforced a decade later. However, subsequent research has suggested that whilst CCTV has certainly given the police new tools in the fight against inner urban crime, it may also have contributed to certain crimes becoming more prevalent elsewhere [11]. Today the increase in the number of cameras in urban areas of Britain has become a human rights issue, and in central London alone, it is estimated that there is now 1 camera for every 14 people. The notion of Britain as a surveillance society of par excellence is part of the Thatcher legacy and it would see that wherever one goes in the city, "big brother" may be watching you.

There were those (not just feminists) who hypothesized back in the 1980s that Margaret Thatcher, as Britain's only female prime minister, would help many more women reach their true potential and break through the glass ceiling in the boardrooms of major companies. The evidence is certainly contested, but it would appear that whilst some gains have been made during the past 30 years, with a minority of women rising to senior positions (especially in United States and more in Scandinavia), the balance of power has altered only very slightly, according to the feminist writer Lynne Segal [12]:

She was the perfect role model for the ever deepening gulf between women, as the privileged few have been able to rise to the very heights of political or corporate power, even as the majority of women, affected at every turn by the rolling back of welfare and the politics of individual success she promoted, are ever more firmly left at the bottom of the heap.

The weakening of the trade unions in Britain after the miners strike in 1984 is seen as one of Thatcher's most notable achievements and the political Left continues to be divided to this day. The labour movement has been in retreat and on the defensive since she left office, a situation reinforced rather than reversed by New Labour under Tony Blair. But if the influence of unions has been reduced, according to Andrew O'Hagan [9, p. 18], it has "left workers with no alternative form of self-esteem or protection and the result today is a workforce of the 
alienated”. Widespread alienation and disaffection can be seen everywhere and many workers feel enslaved by the intensification of all labour processes, something predicted by Harry Braverman [13] in his influential book Labor and Monopoly Capital. The intensification of labour grew during the 1980s and Thatcher made a virtue of this as an index of economic growth and success. She also divisively encouraged her first political lieutenant, Norman Tebbit, to beat the unemployed with a stick telling them to go out and "get on their bikes" to find a job.

The resentment towards Thatcher in Britain's industrial heartland and mining communities is hard to capture, but a walk around those areas today reveals the full extent of the devastation... no jobs, empty shops, boarded up derelict houses, obsolete factory buildings with a rusty sign "keep out-dangerous mine shaft" blowing in the wind. Only the pub or working mens club has survived, just like the saloon bar of a ghost town in a cowboy movie. Here the locals gather to reflect on a life that took a decisive turn for the worse back in 1984. Unfortunately there is no Clint Eastwood or Steven Seagal to come and ride into town and rescue them. Of course, not all of this economic and social decline can be laid at the path of Margaret Thatcher as similar processes can be seen at work in the old industrial areas across Europe and the United States such as Detroit. However, many of the older generation in such communities who haven't worked since the mine closed down back in the 1980s blame Maggie... and then quickly add Tony Blair, for subsequently failing to put things right in solid working class and staunch Labour communities.

In the 1930s George Orwell [14] wrote a book entitled The Road to Wigan Pier, in which the result of his investigation into the working life of industrial workers in the North of England captured the full extent of their hardship and misery. Today in some parts of the North of England the only thing that has changed is that there are no longer any jobs. George Orwell also described Britain as a country of fairness and tolerance, but according to Andrew O'Hagan [9, p. 19], “that is a place that ended with the advent of Mrs Thatcher”. Further, she espoused classical liberal values in the economic sphere but gave us a new and cynical mistrust for the liberal values of fairness, justice and tolerance whenever they posed a challenge to the values of the market [9].

We clearly live in very dangerous, uncertain and troubled times and the passing of Margaret Thatcher provides a timely reminder of where we could be headed... like a large supertanker headed for the rocks but unable to change course. Those who oppose Thatcherism and challenge the status quo and its neoliberal orthodoxy in Britain, United States and Europe, e.g., the influential US economist Paul Krugman [1] and UK social policy academics John Clarke and Janet Newman [2], are likely to be ignored or even marginalized. Such influential critics are clearly out of step with the path of austerity that many of our present political leaders are saying that we have to go down whatever the cost.

\section{References}

[1] Krugman, P. (2013) How the case for Austerity has crumbled. The New York Review of Books.

[2] Clarke, J. and Newman, J. (2012) The alchemy of austerity. Critical Social Policy, 32, 299-319. http://dx.doi.org/10.1177/0261018312444405

[3] Jenkins, S. (2013) Ignore the howls. If bankers leave it would be no great loss. The Guardian, 6 March, 30.

[4] Lillelien, B. (1981) Youtube video commentary in the aftermath of Norway's victory over England in Oslo in 1981. http://youtube.com/watch?v=PqZTP8-8wIs

[5] Nasqvi, S. (2013) Can you be a Tory and a social worker? Professional Social Work, March 2013, 24-25.

[6] Hitchens, P. (2013) Let’s remember Maggie for what she really was... a tragic failure. The Mail on Sunday, 14 April, 35. http://hitchensblog.mailonsunday.co.uk/2013/04/lets-remember-maggie-for-what-she-really-was-a-tragic-failure.html

[7] Stepney, P. (2012) An overview of the wider policy context. In: Stepney, P. and Ford, D., Eds., Social Work Models, Methods and Theories, 2nd Edition, Russell House, Lyme Regis, 1-19.

[8] Paine, T. (1791) The rights of man. Joseph Johnson of Fleet Street, London.

[9] O’Hagan, A. (2013) Maggie. The New York Review of Books, 9, 18-20.

[10] Klein, R. (2013) The new politics of the NHS. 7th Edition, Radcliffe Publishing, Milton Keynes, 67-73.

[11] Pawson, R. and Tilley, N. (1997) Realistic evaluation. Sage, Thousand Oaks.

[12] Segal, L. (2013) Thatcher-Neoliberalism's “willing tool”, Verso Blog. http://www.versobooks.com/blogs/1278-thatcher-neoliberalism-s-willing-tool 
[13] Braverman, H. (1974) Labor and monopoly capital: The degradation of work in the twentieth century. Monthly Review Press, New York.

[14] Orwell, G. (1937) The road to Wigan pier. Gollancz for the Left Book Club, London. 